\title{
AUDITORY PROCESSING DISORDERS: TRAINING OF SPEECH-LANGUAGE THERAPISTS AND AUDIOLOGISTS WITHIN THE SOUTH AFRICAN CONTEXT
}

\author{
Farhana Khan *, Dr. Nicci Campbell ${ }^{*}$ and Professor Brenda Louw * \\ * Department of Communication Pathology, University of Pretoria \\ $¥$ Institute of Sound and Vibration Research, University of Southampton
}

\begin{abstract}
This study examined the nature of the undergraduate curricula for Auditory Processing Disorders (APD) for communication pathologists (speech-language therapists and audiologists) within the South African context. An exploratory descriptive survey design was utilised. The respondents $(N=9)$ were the authoritative voices in the area of $A P D$, i.e. academics based at training institutions involved in the training of Speech-Language Therapists and Audiologists in the field of APD. They represented the five institutions providing training in APD at the time of data collection. A specifically designed questionnaire and the course descriptors and/or study guides were used to obtain information on the APD training programmes at each institution. A curriculum analysis framework was utilised to analyse the curricula (Jansen \& Reddy, 1998). The study found no standard with regard to lecture and clinical time allocation. The time allocated to the theoretical training in APD across the training institutions varied significantly from 4 hours 30 minutes to 53 hours and that for clinical training varied from 7 to 48 hours. However, the results showed that the curricula offered in APD at all training institutions compared favourably with international trends. Information was not forthcoming on how the South African social and contextual issues were incorporated into training in APD.
\end{abstract}

Key Words: Communication pathologist (speech-language therapist and audiologist), curricula, Auditory Processing Disorder, training institutions.

\section{INTRODUCTION}

There has been rapid transformation in the education and training of speech-language therapists and audiologists in the past nine years. This commenced in 1996, when representatives from the universities training programmes met to discuss the development of Speech-language Therapy and Audiology training programmes (Hugo, 1998). The specific focus of the meeting was the development of graduate competency profiles focussing on professional redress and highlighted the need for speech-language therapy and audiology training, to address issues of practice with a black African first language clientele (Hugo, 1998; Pillay, 1997).

The transformation of training of speech-language therapists and audiologists was in line with the constitution of a democratic country which was striving for equal rights for every person, and as such a need to establish an equitable and effective higher education system became a top priority. A transformation process was required that would necessitate the management of cultural diversity, and organisational changes within our institutions of higher learning (Norris, 2000). Linked to transformation in higher education was the reality that as health care professionals, speech-language therapists and audiologists had to accept and acknowledge that they, too, had to be accountable to the post-apartheid society that they now served, especially in terms of the country's constitutional and legislative health aims in addressing demographic inequality (Kathard, 1999).

The challenge that higher education institutions training speech-language therapists and audiologists in South Africa were faced with, was the pressure to meet the needs of the underserved majority. The reality was that the profession of speech-language therapy and audiology had to undergo "radical transformation" (Uys \& Hugo, 1997, p.29) to avoid duplicating the inequities of the past. In South Africa, training institutions now had the responsibility to address not only the disciplinebased knowledge of the area, but of enlightening students about social accountability issues, so that they can critically reflect and articulate the beliefs upon which the profession is based (Kathard, 1999). This transformation had to span all areas of training including, Auditory Processing Disorders (APD).

Training programmes for speech-language therapists and audiologists in APD in South Africa are required to equip students with the necessary competencies enabling them to effectively manage this disorder. A comprehensive review of the literature of the area of APD was undertaken, and the researcher observed that debates still exist in defining, identifying, assessing and providing remediation for a client suspected of presenting with an APD (Bellis, 2003). Against this milieu, South African training programmes have to equip their students to be aware of the issues that prevail in the area of APD, yet they are also faced with unique challenges and difficulties of working within the field of APD (Wilson \& Campbell, 2000). Consequently training programmes for therapists had to reflect the situation that is the reality of their country.

Auditory processing disorders (APD) has been recently defined (ASHA, 2005) as a deficit in neural processing of auditory stimuli that is not due to higher order language, cognitive, or related factors. However, APD may lead to or be associated with difficulties in higher order language, learning, and communication functions. APD is a heterogeneous disorder, resulting in a wide range of variability in the associated problems experienced by children who present with the disorder. APD places the child at risk for developing written language, reading, spelling, and as a result overall academic problems (Schminky \& Baran, 1999).

This emphasises the need for a comprehensive assessment and remediation plan that fully explores the nature of the presenting difficulties of each individual suspected of APD. A collaborative approach that includes the audiologist and speech -language therapist in identification, assessment and remediation of this disorder, especially in children, is therefore recommended (ASHA, 1996; ASHA 2005).

In 2003 Bellis reports that in the past seven years there has been an increase in the awareness of the disorder on the part of professionals, parents, and educators. Personal observa- 
tions of the SA context reveal that speech-language therapists and audiologists are receiving a greater number of referrals for APD assessment. Countless journal articles published internationally are dedicated to the topic and with the recently introduced continuing professional development programme by the Health Professions Council of South Africa (HPCSA), workshops and seminars dedicated to APD are a popular choice. The evaluation and management of APD is within the scope of practice of both audiologists and speech-language therapists and is an accepted clinical activity within the field of communicative disorders (Hall, 1999; HPCSA, 2003; Richard, 2004). However, many speech-language therapists and audiologists feel uncomfortable in evaluating, interpreting and remediating APD, citing lack of course work and knowledge of auditory processing as factors limiting their involvement (Katz, 1994), with dire consequences for a child presenting with APD.

The hesitation expressed by speech-language therapists and audiologists in participating in APD management (Chermak, Traynham, Seikel \& Musiek, 1998; Fourie, 1998), may be attributed to limitations or shortcomings in the training regarding APD (Chermak, et.al., 1998; Keith, 2002; Fourie, 1998). Research exists that confirms that training institutions provide limited training in the area both in the USA (Peck, Gressard, \& Hellerman, 1991; Henri, 1994; Sykes, Tucker and Herr, 1997; Chermak, et.al., 1998; Bellis, 1999 \& 2003) and South Africa (Fourie, 1998). As the education and training of speechlanguage therapists and audiologists in the area of APD has been implicated as a factor contributing to the eventual assessment and management of children presenting with APD both in the United States of America and South Africa, there therefore exists a need for training regarding APD to be investigated.

The current study was positioned in education and this vantage point was used to investigate the nature of the APD curricula (both theoretical and clinical) offered by South African training institutions. The curricula were analysed in order to develop an understanding of what constitutes the training programme regarding APD in South Africa and attempted to determine its influence on clinicians' eventual practice. In addition, the analysis of the curricula assisted the researcher to determine if the curricula in APD are relevant to and deliverable to the communities we serve, as training institutions need to ensure that speech-language therapists and audiologists have the skill and knowledge to provide services to a multi-cultural communication impaired population in South Africa (Hugo, 1998).

\section{METHOD}

\section{Aim}

The main aim of the study was to investigate the nature of the undergraduate curriculum for Auditory Processing Disorders (APD) for Communication pathologists (Speech-language Therapists and Audiologists) within the South African context.The following sub aims delineate the means by which the primary aim of the study was realised.

- . To describe the nature of existing undergraduate APD curricula (theoretical and clinical) offered by tertiary institutions training communication pathologists in South Africa.

- To evaluate the above curricula using a curriculum analysis schema (Jansen \& Reddy, 1998).

\section{Research Design}

To achieve the main aim of the study an exploratory, descriptive survey design was selected for the study. The first was an explo- ration through research of the curricula offered for APD at tertiary institutions. The second was the description of the findings of the curricula offered (Neuman, 1997; Drummond, 1996).

\section{Respondents}

The subject population for this study were the authoritative voices in the area of APD, i.e. academics based at training institutions involved in the training of Speech-language Therapists and Audiologists in the field of APD.

\section{Sampling method}

Comprehensive sampling, which is a purposeful sampling strategy, was utilised. This referred to the situation where every participant, group, setting, event or other relevant information was examined and was the preferred sampling strategy (McMillan \& Schumacher, 2001).

\section{Respondent selection criteria}

The respondents were required:

- To be qualified speech-language therapists and/or audiologists registered with the Health Professions Council of South Africa (HPCSA), as professional registration is required for practice

- To be academic staff based at a tertiary institution involved in the theoretical and / or clinical training of speechlanguage therapists and audiologists in the area of APD.

\section{Sample size.}

Speech-language therapists and audiologists in South Africa are trained at the Universities of Pretoria, Stellenbosch, Kwa Zulu-Natal (formerly, the University of DurbanWestville), Cape Town, Witwatersrand, and MEDUNSA. MEDUNSA was not included in the sample as the university commenced offering a programme for Speech-language therapists and audiologists in February 2001. At the time of data collection, i.e. March 2002, this programme was in its second year and did not offer the APD course both theoretically and clinically. Academic and clinical staff involved in the training of speech-language therapists and audiologists in APD' at the remaining five tertiary institutions constituted the sample.

\section{Respondent selection process}

The Heads of Department at the respective training institutions were contacted telephonically to inform them of the nature and the purpose of the study. Preliminary permission to conduct the study was obtained. The names of staff members involved in the training regarding APD were requested. Subsequently, all respondents identified, i.e. the academic staff directly involved in the training (theoretical and clinical) of speech-language therapists and audiologists in APD were selected for the study. Letters containing the motivation, the nature of the study, the selection procedure of the study, the importance of their participation in the study and the assurance of confidentiality and anonymity were sent to the heads of department and to each respondent. Respondents were asked if they were willing to participate in the study and were requested to complete the questionnaire and return it only if they were willing to do so.

\section{Description of the respondents}

Questionnaires were sent to all five training institutions and responses were obtained from all five. Eleven responses were received out of which nine were selected as respondents. 
Two of the respondents were excluded, as both respondents did not teach directly in the area of APD. The respondents in the study held qualifications at masters and doctoral levels. All respondents had accumulated clinical experience as speech-language therapists and audiologists before joining the respective tertiary training institutions. Furthermore, they had acquired experience specifically as educators training in the area of APD. Their work experience in APD ranged from 6 months to 10 years.

\section{Materials}

A questionnaire (Appendix A and B) and a copy of the course descriptor and / or study guide of each training institution were the main materials utilised in the study. The latter was provided by each training institution that participated in the study.

\section{Procedure}

The research process of the current study was conducted over THREE phases.

\section{Phase One: Preparation Phase and Pilot Study}

\section{Development of the questionnaire.}

A questionnaire was identified as an appropriate tool that enabled the researcher to access a population that was beyond the researcher's physical reach, as the respondents were situated around the country (Leedy, 1997; Neuman, 1997). Due to the nature of the study an open or unrestricted questionnaire was adopted. The aim of the questionnaire was to obtain information on the nature of existing undergraduate APD curricula (theoretical and clinical) offered by tertiary institutions training communication pathologists in South Africa.

The questionnaire comprised of three sections to meet

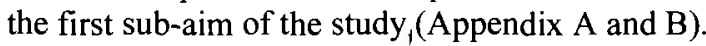

\section{Pilot Study}

This was conducted to determine the suitability of the questionnaire compiled for the current study and to consider further developments to the questionnaire. Two independent candidates who were qualified speech-language therapists and audiologists, and who had prior experience teaching in the area of APD at a tertiary institution, were selected as respondents. They were not included as respondents in the main study. They were requested to indicate if the questions were clear and explore their interpretations to establish whether the intended meaning of the research was clear. Apart from completing the questionnaire the respondents were required to comment critically on all aspects of the instrument. The recommendations of the pilot study entailed minor adjustments to the questionnaire, which were incorporated.

\section{Phase two: data collection and analysis}

\section{Data collection}

The questionnaire was mailed to the respondents via the heads of department at the respective training institutions. The package contained a postage-paid self-addressed envelope, letters to the head of department and to each subject, and the questionnaire. A period of two weeks was stipulated for return of the questionnaires. It was requested that copies of the course descriptor and/or study guide should be included with the completed questionnaire so that additional information related to the questionnaire can be obtained.

Copies of the completed questionnaires were then submitted to the statistician for assistance with data analysis.

\section{Data analyses}

The data was analysed on two levels. Level one analysis related to sub aim one and level two analysis to sub aim two.

Level one analysis involved quantitative and qualitative data analysis, which resulted in the data being organised to identify patterns and categories (Mc Millan \& Schumacher, 2001).

- The questionnaires were analysed quantitatively. Quantitative analysis involved the use of descriptive data analysis techniques, namely frequency counts and measures of central tendency. The completed questionnaires were analysed with the assistance of the Department of Statistics at the University of Pretoria. Quantitative data was represented with the use of tables.

- The study guides and/ or course descriptors attached to the questionnaires were analysed qualitatively. Qualitative data analysis is essentially an inductive process of organising the data into categories and identifying patterns or relationships among the categories (Mc Millan \& Schumacher, 2001). The categories were predetermined and included in the questionnaire. The researcher thus used a priori coding (Bailey, 1997). This form of coding suited the present study as the categories outlined were areas pertaining to the course and are contained in the course descriptor and/ or study guide for a course in APD.

The specified categories are as follows:

1. Aims and objectives of the curriculum.

2. Outcomes of the curriculum, in terms of:

a. Theoretical constructs,

b. Identification of the child with APD,

c. Assessment/evaluation/diagnosis of the child with APD,

3. Management of the child with APD

4. Outline of content areas, i.e. syllabus covered.

5. Teaching methodologies utilised.

6. Resources used (human, physical and technical).

7. Other areas that the respondents wished to include.

With the predetermined categories in place the final and ultimate goal of qualitative analysis made general statements about relationships among these categories by discovering patterns in the data.

Level two analyses involved analysing the curricula utilising a framework for the analysis of a curriculum by Jansen and Reddy (1998). This was utilised to assist with the qualitative analysis of the curricula obtained from the five tertiary institutions. The framework in question was selected, as a dearth of information in the literature on analysis of curricula exists. A curriculum analysis framework for post-apartheid South Africa does not appear to exist, and the model proposed by Jansen and Reddy (1998) has been used extensively to deconstruct curriculum in South Africa (Dr. R. Sookrajh personal communication, October 05, 2004). The framework presented in Table 1 allows for curricula to be analysed in terms of its impact, design or policy (Jansen \& Reddy, 1998). 
Table 1: A framework for the analysis of a curriculum (Jansen \& Reddy, 1998, p.6) Adapted to the current study.

\begin{tabular}{|c|l|l|}
\hline $\begin{array}{l}\text { EXTERNAL } \\
\text { Micro level }\end{array}$ & $\begin{array}{l}\text { IMPACT ANALYSIS } \\
\text { What are the effects of the curriculum and is the } \\
\text { curriculum making a difference? }\end{array}$ & $\begin{array}{l}\text { This was determined by: } \\
- \text { Obtaining a clear understanding of the aims and objectives of the curricula } \\
\text { Obtaining an understanding of the expected outcomes. } \\
\text { Developing insight into the difficulties and challenges encountered in the } \\
\text { area of APD as an educator }\end{array}$ \\
\hline INTERNAL & $\begin{array}{l}\text { DESIGN ANALYSIS } \\
\text { What theories, principles, methods, standards } \\
\text { and assumptions underpin the curriculum? }\end{array}$ & $\begin{array}{l}\text { This was determined by evaluating the curricula in terms of: } \\
- \text { Assumptions - what does the curriculum take for granted. } \\
\text { Claims - what does the curriculum claim will happen to those using or } \\
\text { exposed to the curriculum] } \\
\text { Silences - what does the curriculum say nothing about] }\end{array}$ \\
\hline $\begin{array}{l}\text { EXTERNAL } \\
\text { Macro level }\end{array}$ & $\begin{array}{l}\text { POLICY ANALYSIS } \\
\text { What is the relevance of the curriculum in rela- } \\
\text { tion to a particular set of social policies? }\end{array}$ & $\begin{array}{l}\text { This was determined by considering policy affecting the training of the profes- } \\
\text { sionals, namely, scopes of practice and competencies of the said profession- } \\
\text { als. }\end{array}$ \\
\hline
\end{tabular}

\section{RESULTS AND DISCUSSION}

\section{Nature of undergraduate APD curricula offered at South} African Training institutions

The results that follow answer the first sub aim of the study, i.e. to determine the nature of existing undergraduate APD curricula (theoretical and clinical) offered by tertiary institutions training communication pathologists in South Africa. The results were extracted from the completed questionnaires and course descriptors/ study guides provided by the respondents These results are represented in Table 2.

Table 2 provides an overview of the training schedules offered by the respective training institutions with regard to the theoretical and clinical curricula in APD, and the year of study in which the theoretical and clinical curricula are offered. In addition, the notional hours allocated to the theoretical and clinical curricula in APD across the five training institutions are represented. To ensure anonymity the training institutions are referred to as A, B, C, and D AND E.

Table 2: Overview of the theoretical and clinical training schedules .

\begin{tabular}{|c|c|c|c|c|c|c|c|}
\hline \multirow[t]{2}{*}{$\begin{array}{l}\text { Training } \\
\text { Institution }\end{array}$} & \multirow[t]{2}{*}{$\begin{array}{l}\text { Nature of } \\
\text { training }\end{array}$} & \multicolumn{2}{|c|}{$\begin{array}{l}\text { Year of study when train- } \\
\text { ing is provided }\end{array}$} & \multicolumn{2}{|c|}{$\begin{array}{c}\text { Training provided to Audiology and/or } \\
\text { Speech-Language } \\
\text { Therapy Students }\end{array}$} & \multicolumn{2}{|c|}{ Notional hours dedicated to training } \\
\hline & & $\begin{array}{l}\text { Theoretical } \\
\text { Training }\end{array}$ & $\begin{array}{l}\text { Clinical } \\
\text { Training }\end{array}$ & $\begin{array}{l}\text { Theoretical } \\
\text { Training }\end{array}$ & $\begin{array}{l}\text { Clinical } \\
\text { Training }\end{array}$ & $\begin{array}{l}\text { Theoretical } \\
\text { Training }\end{array}$ & Clinical training \\
\hline $\mathbf{A}$ & $\begin{array}{l}\text { Theoretical } \\
\text { and clinical }\end{array}$ & $\begin{array}{l}2^{\text {nd }} \text { and } 3^{\text {rd }} \\
\text { year of } \\
\text { study }\end{array}$ & $\begin{array}{l}3^{\text {rd }} \text { and } 4^{\text {th }} \\
\text { year of } \\
\text { study }\end{array}$ & $\begin{array}{l}\text { Offered as combined } \\
\text { lectures to AUD and SLT } \\
\text { students. } \\
\text { SLT and AUD students } \\
\text { offered additional lectures } \\
\text { separately as well }\end{array}$ & $\begin{array}{l}\text { Separate clinical } \\
\text { training for SLT } \\
\text { and AUD students }\end{array}$ & $\begin{array}{l}\text { Comprises of: } \\
2^{\text {nd }} \text { year: } 23 \text { hours } 30 \\
\text { minutes } \\
3^{\text {rd }} \text { year SLT: } 16 \\
\text { hours } 40 \text { minutes } \\
3^{\text {rd }} \text { year AUD: } 5 \\
\text { hours }\end{array}$ & $\begin{array}{l}\text { Comprises of: } \\
3^{\text {rd }} \text { year SLT and } \\
\text { AUD students: } 10 \\
\text { hours } \\
4^{\text {th }} \text { year SLT' and } \\
\text { AUD students: } 10 \\
\text { hours }\end{array}$ \\
\hline $\mathbf{B}$ & $\begin{array}{l}\text { Theoretical } \\
\text { and clinical }\end{array}$ & $\begin{array}{l}3^{\text {rd }} \text { year of } \\
\text { study }\end{array}$ & $\begin{array}{c}4^{\text {th }} \text { year of } \\
\text { study }\end{array}$ & $\begin{array}{l}\text { Offered as combined } \\
\text { lectures to SLT and AUD } \\
\text { students }\end{array}$ & $\begin{array}{l}\text { Separate clinical } \\
\text { training for SLT } \\
\text { and AUD students } \\
\text { conducled. }\end{array}$ & 18 hours & $\begin{array}{l}4^{\text {th }} \text { year SLT stu- } \\
\text { dents: unspecified } \\
4^{\text {th }} \text { year AUD stu- } \\
\text { dents: } 24-48 \text { hours }\end{array}$ \\
\hline C & $\begin{array}{c}\text { Theoretical } \\
\text { only }\end{array}$ & $\begin{array}{l}3^{\text {rd }} \text { year of } \\
\text { study }\end{array}$ & $\begin{array}{l}\text { None of- } \\
\text { fered }\end{array}$ & $\begin{array}{l}\text { Offered as combined } \\
\text { lectures to SLT and AUD } \\
\text { students. } \\
\text { AUD students receive } \\
\text { additional lectures sepa- } \\
\text { rately. }\end{array}$ & None offered & 12 hours & None \\
\hline D & $\begin{array}{l}\text { Theoretical } \\
\text { and clinical }\end{array}$ & $\begin{array}{l}2^{\text {nd }} \text { and } 4^{\text {th }} \\
\text { years of } \\
\text { study }\end{array}$ & $\begin{array}{l}4^{\text {th }} \text { year of } \\
\text { study }\end{array}$ & $\begin{array}{l}\text { Offered as combined } \\
\text { lectures to SLT and AUD } \\
\text { students }\end{array}$ & $\begin{array}{l}\text { Combined clinical } \\
\text { training for SLT } \\
\text { and AUD students } \\
\text { conducted }\end{array}$ & 4 hours 30 minutes & $\begin{array}{l}4^{\text {th }} \text { year: SLT and } \\
\text { AUD students: } 7 \\
\text { hour's }\end{array}$ \\
\hline$E$ & $\begin{array}{l}\text { Theoretical } \\
\text { and clinical }\end{array}$ & $\begin{array}{l}3^{\text {rd }} \text { year of } \\
\text { study }\end{array}$ & $\begin{array}{l}4^{\text {th }} \text { year of } \\
\text { study }\end{array}$ & $\begin{array}{l}\text { Offered as combined } \\
\text { lectures to SLT and AUD } \\
\text { students }\end{array}$ & $\begin{array}{l}\text { Combined clinical } \\
\text { training for SLT } \\
\text { and AUD students } \\
\text { conducted }\end{array}$ & 53 hours & $\begin{array}{l}\text { The respondent did } \\
\text { not specify the num- } \\
\text { ber of hours. }\end{array}$ \\
\hline $\begin{array}{l}\text { AUD } \\
\text { SLT }\end{array}$ & udiology $\mathrm{s}$ & nly & & & & & \\
\hline
\end{tabular}




\section{Overview of the theoretical and clinical training schedule}

All institutions indicated that both speech-language therapy and audiology students received theoretical training in APD. Noteworthy was that all institutions offered combined lectures for both speech-language therapy and audiology students, whilst two of the five institutions offered additional lectures separately as well. Four of the five institutions indicated that students received clinical training in the area of APD. Institution $C$ was not offering a clinical curriculum in APD at the time of the study. Although clinical training was being offered at Institution $\mathrm{E}$, the number of hours dedicated to the training was unspecified with no supporting reasons provided.

These results indicated a commitment by all five training institutions to training in APD. Speech -language therapists and audiologists qualifying in South Africa exit their respective programmes with exposure to theoretical training in APD and those from all but one of the training institutions will exit with exposure to clinical training in APD.

At the time of data collection (March 2002), training institutions A and D offered a single qualification in Speechlanguage Therapy and Audiology, with dual registration at the HPCSA. Additionally training institutions A, B and C offered the qualification in either Speech-language Therapy or Audiology, with single registration at the HPCSA. Training institution $E$ offered the qualification in Speech-language Therapy and Audiology, with dual registration at the HPCSA, as well as the qualification for Speech-Language Therapy only with single registration at the HPCSA. This information was relevant at the time of data collection as some programmes may have been modified since.

Despite the differences in the qualifications offered at the respective training institutions, theoretical training at all and clinical training at four of the five training institutions were offered to both speech-language therapy and audiology students in APD. As both speech-language therapy and audiology students are trained in APD, it has implications for assessment and remediation as a multidisciplinary team approach to APD is recommended and necessary to effectively assess the cluster of problems that are often seen in those with APD (ASHA, 2005). A multidisciplinary approach is repeatedly emphasised in literature (ASHA, 1996 \&'2005; Bellis, 2003; Bellis, 2004; Keith, 2002; Chermak, 2003), particularly a collaborative approach between the speech-language therapist and audiologist. The speech-language therapist has been identified as fundamental to the broader assessment and remediation of children presenting with APD (Wertz, Hall \& Davis, 2002). Training for speech-language therapists and audiologists are provided by the same departments at the respective training institutions, therefore, opportunities exist for demonstrating and endorsing collaborative teamwork, thus facilitating an integrated approach to APD management.

\section{Notional hours allocated to the theoretical training curricula in $\boldsymbol{A P D}$.}

The time allocated to the theoretical curriculum in APD varied across all institutions. The institutions were divided with regard to whether time allocated for the theoretical training in APD was adequate.

The time allocated to the theoretical training in APD across the training institutions in South Africa varied significantly from 4 hours 30 minutes to 53 hours. New sentence: This can be compared to the 34 hours offered by Bellis (2002) to Audiology graduate students in the US. A comparison was drawn between the South African and USA situations as there was research documenting evidence of training in APD in the
USA. Additionally, the researcher was attempting to position the results obtained for the theoretical training offered in APD in South Africa, against training offered in another country. The findings of the present study supports a study conducted by Fourie (1998) in the Gauteng region in South Africa. Fourie (1998) reported that of the $76 \%$ of the respondents who received training in the area of APD, only $19 \%$ indicated that they had received comprehensive training in the area with $53 \%$ reporting very little training. Fourie (1998) noted that the subjects expressed an overall lack of knowledge of and insight in APD. Although the results of the present study indicate that student speech-language therapists and audiologists DO receive training in the area of APD, the results raise a question: could the widespread difference in time allocated to the theoretical and clinical curricula be a reason for the result seen by Fourie (1998)?

A further question raised by the results of the current study, is: if an imbalance in the time allocated to the theoretical training is seen, is it possible that parity could exist across all training institutions with regard to the theoretical training in APD? There thus appeared to be a need to revisit the time allocation not only to the theoretical curriculum in APD but to examine the time allocation within the framework of the entire programme for speech-language therapists and audiologists at the training institutions under study.

\section{Notional hours allocated to clinical training in APD}

Four of the five institutions indicated that dedicated clinical training in APD was offered to both speech-language therapy and audiology students. The notional hours allocated to clinical training in APD ranged from 7 to 48 hours, over either the $3^{\text {rd }}$ and $/$ or $4^{\text {th }}$ year of study with the time allocation unspecified at institution $B$ and $E$.

The clinical training was accomplished by observation, direct assessment of a client and direct remediation. However, it is apparent that all facets of clinical training were not accomplished at all training institutions. Institution $A$ appeared to offer the most widespread form of clinical training to both their speech-language therapy and audiology students in APD, with all three facets of clinical training offered. At Institution B, for the Audiology students, $90 \%$ of clinical time was assigned to APD assessment; the remaining $10 \%$ comprised therapy in the form of home programmes to both the teacher and parent. At Institution $\mathrm{E}$, the respondent indicated that cases are referred for specialised APD testing within the hearing clinic on campus. Institution D offered a school-based clinic for students in the dual qualification in both assessment and therapy of APD in children.

To summarise, the findings of the present study appeared to indicate a positive situation for South Africa. Although the researcher found no standard with regard to lecture and time allocation, or the year in the programme when training in APD should occur, all training institutions under study offered a commitment to theoretical and most to clinical training in APD. Additionally, the recently drafted competency profiles for the newly qualified audiologist and speech-language therapist compiled by the Professional Board for SpeechLanguage and Hearing Professions of the Health Professions Council of South Africa (HPCSA, 2003), clearly outlined the competencies that are required by the speech-language therapist and audiologist in the area of APD. In this document it is stated that traditionally the client presenting with APD was specified in the client base of the audiologist alone; however, due to the complexities of this condition and the relationship with language processing, the speech-language therapist was 
required to be involved in management of APD.

ln light of these competency profiles drawn up for speech-language therapists and audiologists and the disparity observed in this study regarding the time allocation for theoretical and clinical training in APD, together with the findings by Fourie (1998), it is recommended that an academic steering committee be convened where academics from all training institutions in South Africa collaborate. The function of the committee would be to oversee, evaluate and streamline existing training programmes for speech-language therapists and audiologists in South Africa.

The allocation of time to a particular theoretical module cannot be assigned rigidly but has to be re-considered in light of the entire training programme. It can also be argued that parity in time spent in training is not as important as parity in training objectives and outcomes of the training programmes. Therefore, it is recommended that an academic steering committee be implemented to ensure that graduates leave with equal or similar training opportunities enabling efficient and effective service delivery. This may prevent the situation where graduate speech-language therapists and audiologists exit training programmes feeling an overall lack of knowledge and insight into APD practice.

\section{Presentation of the APD course descriptors using predeter- mined categories}

Table 2 and the preceding results were obtained following analysis of the information obtained in the questionnaires. In addition to the completed questionnaires, all respondents were asked to provide a course descriptor/ study guide with a comprehensive course outline for both the theoretical and clinical curricula in APD. The course descriptors referred to the document that contained information compiled according to a set format that described the module taught. These were analysed and represented according to the predetermined categories presented earlier under data analysis.

\section{Aims and objectives of the APD curricula}

Table 3 contains the aims and objectives of the curricula in APD as indicated by the training institutions under study.

From Table 3 it was evident that the curricula were designed to provide the students with theoretical knowledge necessary in understanding the nature of APD and management in the clinical setting. A comparison was made with the curriculum offered by Bellis (2002) a leading researcher in the field of
APD, to determine if the curricula offered locally are internationally competitive. In terms of the aims and objectives of the respective curricula, the researcher determined that they compared well to the curriculum offered by Bellis (2002) (Appendix C).

Apart from being internationally competitive the curricula offered locally have to be relevant for the South African context. All training institutions did not explicitly indicate whether an aim of the curriculum would be to allow students the opportunity to critique the concept of APD as it related to the South African situation or for critical learnership to equip students with the ability to apply the theory and practice of APD to the South African context. Application and critique of knowledge in APD to the South African context is critical. Based on the South African context the curriculum should be viewed as a dynamic entity for facilitating practice during this dynamic period of social transformation (Pillay, Kathard \& Samuel, 1997). It is now a necessity that an aim and objective of any curriculum as part of the training programme for speech -language therapists and audiologists should feature issues that pertain to the South African context.

\section{The outcomes of the APD curricula}

The outcomes of the APD curricula as indicated by the training institutions under study are presented in Table 4.

The training institutions indicated that understanding the theoretical constructs of APD; the neuro-anatomy, physiology, maturation and plasticity; identification of the child with APD, assessment/evaluation/diagnosis of the child with APD and management of the child with APD were identified as outcomes. Learning outcomes are what the learners should be able to do at the end of their period of training and that educators would like graduates to be able to do as a result of their learning (Boughey, 2005). The outcomes appeared to be comprehensive covering all pertinent areas of APD as per international guidelines and research (ASHA, 1996 \& 2005; Bellis, 2003). However, a critical appraisal of the essential knowledge areas with regard to the South African context was not highlighted.

\section{Outline of the APD syllabi.}

All training institutions under study offered an outline of the syllabi for the theoretical curricula offered in APD to the speech-language therapy and audiology students. This is presented in Table 5 .

Table 3: The aims and objectives of the APD curricula offered at training institutions in South Africa.

\begin{tabular}{|c|c|c|c|c|c|}
\hline \multirow{2}{*}{ CATEGORIES } & \multicolumn{5}{|c|}{ INSTITUTION } \\
\hline & Institution A & Institution B & Institution C & Institution D & Institution E \\
\hline $\begin{array}{l}\text { 1. Aims and objec- } \\
\text { tives of the curricula. }\end{array}$ & $\begin{array}{l}\text { To equip the student with } \\
\text { the necessary theoretical } \\
\text { background knowledge } \\
\text { and clinical skills that } \\
\text { they will need in manag- } \\
\text { ing auditory processing } \\
\text { disorders in the clinical } \\
\text { setting. Furthermore, it is } \\
\text { hoped that this module } \\
\text { will stimulate further re- } \\
\text { search in the field of } \\
\text { auditory processing. }\end{array}$ & $\begin{array}{l}\text { To provide learning } \\
\text { opportunities to facili- } \\
\text { tate an understand- } \\
\text { ing of the nature and } \\
\text { management of cen- } \\
\text { tral auditory process- } \\
\text { ing disorders in chil- } \\
\text { dren. }\end{array}$ & $\begin{array}{l}\text { To provide theoreti- } \\
\text { cal knowledge re- } \\
\text { garding the evalua- } \\
\text { tion of the central } \\
\text { auditory nervous } \\
\text { system. }\end{array}$ & $\begin{array}{l}\text { No aims or objectives } \\
\text { were provided in the } \\
\text { course descriptor }\end{array}$ & $\begin{array}{l}\text { To familiarise the } \\
\text { student with the } \\
\text { diagnosis and reha- } \\
\text { bilitative responsibili- } \\
\text { ties of the audiologist } \\
\text { of individuals with } \\
\text { APD's. }\end{array}$ \\
\hline
\end{tabular}




\begin{tabular}{|c|c|c|c|c|c|}
\hline \multirow{2}{*}{ CATEGORIES } & \multicolumn{5}{|c|}{ INSTITUTION } \\
\hline & A & B & c & $D$ & $E$ \\
\hline $\begin{array}{l}\text { 2. Outcomes of the curric- } \\
\text { ula, in terms of: } \\
\text { a. Theoretical constructs, } \\
\text { b. Identiflcation of the child } \\
\text { with APD, } \\
\text { c. Assessment/ evaluation' } \\
\text { diagnosis of the child with } \\
\text { APD, } \\
\text { d. Management of the child } \\
\text { with APD. }\end{array}$ & $\begin{array}{l}\text { Specific outcomes in terms of essential knowledge for the } \\
\text { curricula at } 2^{\text {nd }} \text { year were provided. } \\
\text { - Discuss the anatomy and physiology of the CANS } \\
\text { - Discuss the prenatal development, neuro-maturation and } \\
\text { plasticity of the CANS } \\
\text { - Appraise the effects of pathology on the CANS } \\
\text { - Compare the differences between organic and functional } \\
\text { lesions of the CANS } \\
\text { - Compile a management program for clients with organic } \\
\text { lesions of the CANS } \\
\text { - Provide a definition of APD and evaluate it against the back- } \\
\text { ground of the controversy which surrounds the field of APD } \\
\text { Examine the causes of APD } \\
\text { - Describe the behaviour of children and adults with APD } \\
\text { - Evaluate the use of sub profiles in the management of APD } \\
\text { - Prspose and motivate which team members you would in- } \\
\text { - lude in the APD team as well as the role of each member. } \\
\text { - Evaluats the current status of assessment toois in the fieid of } \\
\text { APD from the perspective of both the Speech-language } \\
\text { Therapist and Audiologist. } \\
\text { - Compose guidelines for when the audiologist sheuld consider } \\
\text { diagnostic testing \& Evaluate the use of sub profiles in the } \\
\text { managernent of APD } \\
\text { - Propose and motivate which team members you would in- } \\
\text { clude in the APD team as well as the role of each member. } \\
\text { - Evaluate the current status of assessment tocis in the fleid of } \\
\text { APD from the perspective of both the Speech-language } \\
\text { Therapist and Audiologist. } \\
\text { - Compose: guldelines for when the audiologist should consider } \\
\text { diagnostic testing }\end{array}$ & $\begin{array}{l}\text { - The student shall demonstrate } \\
\text { an understanding of the nature } \\
\text { of central auditory processing } \\
\text { disorders in children, and dem- } \\
\text { onstrate knowiedge about the } \\
\text { assessment and treatment } \\
\text { principles and methodologies. }\end{array}$ & $\begin{array}{l}\text { - To provide the rationale and } \\
\text { purpose for conducting evaiua- } \\
\text { tions of the central audltory } \\
\text { nervous system (CANS). } \\
\text { - To familiarise the students with } \\
\text { assessment protocols and meth- } \\
\text { ods uised in the evaluation of the } \\
\text { CANIS. } \\
\text { - To be able to interpret test find- } \\
\text { ings and provide appropriate } \\
\text { recommendations for manage- } \\
\text { ment using current models and } \\
\text { theory. }\end{array}$ & $\begin{array}{l}\text { - On completion of the course } \\
\text { students will understand the } \\
\text { relationship of APD to hear- } \\
\text { ing loss. } \\
\text { - They will be able to describe } \\
\text { the neuroanatomy and } \\
\text { neurephysiology of hearing } \\
\text { and how this relates to the } \\
\text { basic concepts underlying } \\
\text { APD testing. } \\
\text { - They will be able to identify } \\
\text { clients at risk for APD }\end{array}$ & $\begin{array}{l}\text { - Discuss the function of specific } \\
\text { central auditory structures } \\
\text { - Define central auditory processes } \\
\text { - Explair the effect of pathology of } \\
\text { - the central auditory system } \\
\text { - Discuss hemispheric specialisa- } \\
\text { - ion } \\
\text { - Identify auditory tasks that de- } \\
\text { pend on temporal processing and } \\
\text { binaural interaction. } \\
\text { - Explain the principles of the } \\
\text { evaluation of APD and to perform } \\
\text { some tests } \\
\text { - Be able to differentiate between } \\
\text { categories of APD } \\
\text { - To integrate the evaluation of } \\
\text { language with the central auditory } \\
\text { test battery } \\
\text { - Be able to interpret the result of a } \\
\text { test battery } \\
\text { - Select the rehabilitation principles } \\
\text { for different cases and appiy } \\
\text { auditory, meta-linguistic and } \\
\text { cognitive strategles. }\end{array}$ \\
\hline $\begin{array}{l}\text { 3. Outline of content ar- } \\
\text { eas, i.e. syllabi covered. }\end{array}$ & $\begin{array}{l}\text { - Anatomy and physiology of the CANS } \\
\text { Prenatal devilopment, neuro-maturation and plasticity of the } \\
\text { CANS } \\
\text { - Effects of pathology on the CANS } \\
\text { - The differences between organic and functional lesions of the } \\
\text { CANS } \\
\text { - The management program for clients with organic lesions of } \\
\text { the CANS } \\
\text { - Causes, symptoms, assessment \& rehabilitation and team- } \\
\text { work. } \\
\text { What is an APD? Definition, theories, approaches and co- } \\
\text { existing disorders. } \\
\text { - Causes of APD } \\
\text { The behaviour of children and adults with APD } \\
\text { Types and sub profiles of APD } \\
\text { - The APD team. }\end{array}$ & $\begin{array}{l}\text { - Introduction } \\
\text { - Terminology } \\
\text { - Perspectives on auditory proc- } \\
\text { essing } \\
\text { - Neuro-anatomy, Physiology and } \\
\text { Specialised Functions of the } \\
\text { - Central Auditory Mechanism } \\
\text { - Auditory precessing of Speech } \\
\text { - Development of auditory proc- } \\
\text { essing. } \\
\text { - Implications for assessment of } \\
\text { auditory processing. } \\
\text { - Auditory processing disorders } \\
\text { - What is a central auditory proc- } \\
\text { essing disorder? } \\
\text { - Defiritions and concepts } \\
\text { - Nature of Auditory Processinc } \\
\text { Disorders } \\
\text { - Factors associated with ar } \\
\text { auditory processing dysfunctlon } \\
\text { including Otitis media. } \\
\text { - Causes of auditory processing } \\
\text { disorders }\end{array}$ & $\begin{array}{l}\text { - Introduction and terminology } \\
\text { - Types and subgroups of APD } \\
\text { - Development of auditory function } \\
\text { - Principles which can be applied } \\
\text { to functional evaluation of the } \\
\text { cans } \\
\text { - Behavioural measures of central } \\
\text { auditory function using monaural } \\
\text { stimuli } \\
\text { - Behavioural measure of central } \\
\text { auditory function using dichotic } \\
\text { stimuli } \\
\text { - Electrophysiological measures of } \\
\text { the central audittory system } \\
\text { - Limithations of central auditory } \\
\text { measures } \\
\text { - Localisabie neural hearing de- } \\
\text { fects } \\
\text { - Diffuse centrat hearing defects. } \\
\text { - Fseudo central hearing loss. }\end{array}$ & $\begin{array}{l}\text { - Background Definition: what } \\
\text { is central auditory process- } \\
\text { ing } \\
\text { - Review of the neuro- } \\
\text { anatomy and neuro- } \\
\text { physiology of the auditory } \\
\text { system. } \\
\text { - Basic concepts underlying } \\
\text { the assessment of APD: } \\
\text { a. Dichotic listening } \\
\text { b. Temporal processirig } \\
\text { c. Binaural interaction } \\
\text { - Implications of neuro- } \\
\text { maturation and neuro- } \\
\text { plasticity of the auditory } \\
\text { 3ystem for intervention } \\
\text { - Who should be tested and } \\
\text { who should be involved in } \\
\text { APD? The role of the audi- } \\
\text { ologist as a team member } \\
\text { - Overiew of the central tests } \\
\text { (in relation to the basic } \\
\text { concepts) } \\
\text { - Specific tests } \\
\text { Interpretation of results } \\
\text { - Management }\end{array}$ & $\begin{array}{l}\text { Not specified but can be extracted } \\
\text { from the outcomes of the course. }\end{array}$ \\
\hline
\end{tabular}


The syllabi provided on the course descriptors were analysed qualitatively in terms of theoretical constructs, identification of the child with APD, assessment/ evaluation/ diagnosis of the child with APD and the management of the child with APD. Patterns in the data were identified and compared to research in the field of APD.

The qualitative analysis indicated that most of the training institutions under study appeared to cover all areas as per the predetermined categories. Although the curricula differed in terms of comprehensiveness, they appeared to be congruent with the time allocated to the module. Overall the outline syllabi incorporated the fundamental areas required to equip the graduate speech-language therapist and audiologist with the necessary theoretical background knowledge that they will require in managing auditory processing disorders in the clinical setting, in line with research in the field of APD (Jerger \& Musiek, 2000 \& 2002; Bellis, 2003; ASHA, 1996 \& 2005; Katz, 2002; HPCSA, 2003).

The curricula in APD offered by South Africa training institutions equip both speech-language therapists and audiologists in all areas of APD, theoretically and clinically and are guided by the HPCSA (2003) competency profiles with regards to standards and guidelines in terms of practice for both speech -language therapists and audiologists in the area of APD.

In addition, the curricula reflected research trends in the field of APD and compared well to the curriculum described by Bellis (2002). Training institutions in South Africa are commissioned with an added responsibility of training students to provide an appropriate and relevant service to all clients within the South African context. There did not appear to be direct evidence of this in the curricula provided. There is a need for student speech-language therapists and audiologists to be well versed with issues and challenges faced by the wide spectrum of clients seen in the South African context and to apply this knowledge and skill critically to these clients (Uys \& Hugo, 1997).

\section{Evaluation of the curricula obtained from training institu- tions in South Africa, using a curriculum analysis schema (Jansen \& Reddy, 1998)}

Curriculum studies refer to an area of inquiry in higher education that focuses on what is learned and should be learned in educational institutions (Schubert, 1986). Many images of curriculum exist, e.g. the most traditional is curriculum as content or subject matter, or curriculum as intended learning outcomes (Schubert, 1986). The current study attempted to view curriculum as a field of inquiry and practise. The character of curriculum shapes and is shaped by its external relationships with knowledge, perspectives and practice (Schubert, 1986). As a result a curriculum in APD being offered at tertiary institutions in South Africa has to account for the South African context. Training institutions can utilise the research, guidelines and curricula from countries like the United States of America, but cannot ignore the needs of the clients within South Africa. What therefore, emerges is the need for a curriculum distinct for the South African context.

Training institutions need to ensure that speechlanguage therapists and audiologists have the skill and knowledge to provide services to a multi-cultural communication impaired population in South Africa (Hugo, 1998).

In an attempt to determine if the curricula offered by the training institutions were training for the South African context, the purpose of the second sub aim of the study was to evaluate the curricula using a curriculum analysis schema
(Jansen \& Reddy, 1998). The course descriptors that were completed and provided by the respondents were evaluated by applying the curriculum analysis schema. They were analysed in terms of Impact, Design and Policy (Jansen \& Reddy, 1998). These results are summarised in Table 6 .

With regard to the impact analysis the curricula were first evaluated in terms of the aims and objectives of the curricula. The latter form the basis for what is to be learned, how well it is to be performed, and under what conditions it is to be performed (Clark, 2000). By perusing through the aims and objectives of each curriculum (Table 3 ), it was clear that they shared a common thread amongst the institutions. A key feature of an impact analysis is to ascertain the effect of the curriculum and to determine if the curriculum is making a difference. It can therefore be observed that all training institutions under study are taking a positive step in training speechlanguage therapists and audiologists by exposing them both to the disorder.

In terms of the expected outcomes, due to some institutions allocating more time to the theoretical curriculum in APD, they presented with a more comprehensive set of outcomes (refer to Table $4 \& 6$ ). A comprehensive list of outcomes conveys the exact training requirement to the student (NCGIA GISCC, 2005).

At all five training institutions under study the outcomes of the curricula in APD applied to both the speech-language therapy and audiology students despite differences in the qualifications offered. Literature on APD has recurrently indicated that in addition to auditory processing difficulties, school aged children diagnosed with APD may experience associated learning difficulties (e.g. spelling, reading and speech and language problems) (ASHA, 2005). The presence of these associated difficulties highlights the fundamental role that speechlanguage therapists have in the broader assessment and management of individuals with APD (Wertz, et.al, 2002). An awareness of this integral relationship that audiologists and speech-language therapists share was demonstrated by all training institutions under study. This trend observed in the training was in keeping with literature that advocates a multidisciplinary approach to APD assessment and remediation (ASHA, 1996; ASHA, 2005; Bellis, 2003; Bellis, 2004; Keith, 2002; Chermak, 2003; HPCSA, 2003).

The difficulties and challenges encountered in the area of APD as educators within the South African context, formed part of the impact analysis. These are summarised in Table 6.

Although many of the training institutions cited a lack of standardised and linguistically and culturally appropriate tools as a shortcoming in our country specifically in the area of APD, this issue did not appear to be raised nor explicitly stated in the aims and outcomes as a key and focus area in the training, i.e. in the theoretical course. Although the issue of a lack of standardised and linguistically and culturally appropriate tools for APD assessment did not appear to be overtly stated in the aims and neither objectives, nor the outcomes of the course descriptors provided, the training institutions did inform students of the work of the now disbanded South African APD taskforce, (Wilson and Campbell, 2000). The taskforce compiled a test battery with a low-linguistic load which could be used in the interim until diagnostic materials for all language groups could be developed. The researcher therefore, speculates that issues pertaining to the lack of standardised and linguistically and culturally appropriate tools for South Africa were probably covered in these curricula. 
Table 6: A framework for the analysis of a curriculum (Jansen \& Reddy, 1998, p.6).

\begin{tabular}{|c|c|}
\hline $\begin{array}{c}\text { ANAL YSIS TYPE } \\
\text { (Jansen \& Reddy, 1998). }\end{array}$ & CRITICAL EVALUATION OF CURRICULA \\
\hline $\begin{array}{l}\text { IMPACT ANALYSIS } \\
\text { What are the effects of the } \\
\text { curriculum and is the curricu- } \\
\text { lum making a difference? }\end{array}$ & $\begin{array}{l}\text { The results on the analysis in terms of : } \\
\text { - The aims and objectives of the curricula } \\
\text { - The curricula were designed to provide the learner with the opportunity to assess and remediate clients who presented with APD and to } \\
\text { provide them with the theoretical knowledge to do so. } \\
\text { - The expected outcomes. } \\
\text { - Were clearly stipulated by all institutions with students provided with a comprehensive description of the outcomes of the curriculum. } \\
\text { - The outcomes for the curniculum in APD were stipulated in terms of the theoretical constructs, identification of the child with APD, as- } \\
\text { sessment evaluation/ diagnosis of the child with APD and management of the child with APD. } \\
\text { - The difficulties and challenges encountered in the area of APD as an educator } \\
\text { - These ranged from poor access to assessment materials and specifically the lack of standardised assessment materials in the area of } \\
\text { APD suitable for the South African context, coupled with financial constraints of the training institutions. } \\
\text { - The respondents acknowledged that these challenges impacted negatively on the clinical training of the audiology and speech- } \\
\text { language therapy student. }\end{array}$ \\
\hline $\begin{array}{l}\text { DESIGN ANALYSIS } \\
\text { What theories, principles, } \\
\text { methods, standards and } \\
\text { assumptions underpin the } \\
\text { curriculum? }\end{array}$ & $\begin{array}{l}\text { This was determined by evaluating the curricula in terms of: } \\
\text { - Assumptions - what does the curriculum take for granted } \\
\text { - The areas stipulated on the outline syllabus, i.e. theoretical constructs, identification of the child with APD, the diagnosis and assess- } \\
\text { ment and management of the child with APD, can be viewed as an assumption (Jansen \& Reddy, 1998). } \\
\text { - All the training institutions assumed or took for granted that the areas covered under the outline syllabus were sufficient for a training curriculum in } \\
\text { APD and sufficient to enable an assessment and remediation of a child presenting with APD. } \\
\text { - Claims - what does the curriculum claim will happen to those using or exposed to the curriculum } \\
\text { - All the training institutions claimed that the curricula were designed to provide the student with theoretical knowledge necessary in } \\
\text { understanding the nature of APD and the management in the clinical setting, and the clinical exposure to do so. } \\
\text { - An inherent claim was that the knowledge imparted was adequate to meet this outcome and that the students possessed sufficient } \\
\text { knowledge to meet the needs of the clients that they would serve. } \\
\text { - Silences - what does the curriculum say nothing about } \\
\text { - The lack of information and emphases in the course descriptors of issues peculiar to the South African situation. These are issues } \\
\text { pertaining to the lack of standardised assessment and linguistically appropriate tools for APD, as well as issues pertaining to diversity. } \\
\text { Additionally, broader issues that affect a large proportion of South Africans. These are the issues of poverty with all its social, economi- } \\
\text { cal and educational sequelae, and the effect of the HIVIAIDS pandemic specifically on speech, language and hearing development } \\
\text { amongst others is required to be considered (Druck \& Ross, 2002). }\end{array}$ \\
\hline $\begin{array}{l}\text { POLICY ANALYSIS } \\
\text { What is the relevance of the } \\
\text { curriculum in relation to a } \\
\text { particular set of social poli- } \\
\text { cies? }\end{array}$ & $\begin{array}{l}\text { This was determined by considening policy affecting the training of the professionals, namely, scopes of practice and competencies of the said } \\
\text { professionals. } \\
\text { - The professional training of speech-language therapists and audiologists are guided by the policies of the HPCSA. }\end{array}$ \\
\hline
\end{tabular}

An impact analysis is measured to determine if a curriculum is relevant and effective, and to determine which parts of the curriculum should be strengthened or removed (Jansen \& Reddy, 1998). Although the researcher concluded that the aims and objectives and the outcomes of the curricula clearly reflected an appropriate and accurate curricula for managing a client with APD in keeping with literature in the field of APD, the researcher questions the application of the curricula for the greater South African context! It is recommended that in order to strengthen the impact of the curricula the students have to be prepared with the skills to do and the inclination and skill to analyse what they do in terms; of its consequences on the clients whom they serve (Mokgalabone, 1998).

This second aspect of the curriculum analysis process proposed by Jansen and Reddy (1998) was the design analysis. In order to evaluate a curriculum according to the design principles, Posner (1992, in Jansen, 1998) offered a model to probe the design of the curriculum. He recommended examining the curriculum in terms of assumptions, claims and silences.

\section{Assumptions [what does the curriculum take for granted].}

Uncovering the assumptions is a subjective process and when evaluating curricula there is often a lack of awareness of the assumptions that influence the curricula. The researcher therefore revealed that the training institutions speculated that the curricula offered were suitable for training in the area of APD in South Africa. However, the respondents acknowledged that as educators in the area of APD they were faced with certain challenges. A major challenge facing most training institutions was poor access to resources, i.e. there is a lack of appro- priate assessment materials coupled with financial constraints (Campbell \& Wilson, 2001).

Claims [what does the curriculum claim will happen to those using or exposed to the curriculum]

The claims were drawn from the outcomes presented in the course descriptors. An inherent claim was that the knowledge imparted was adequate to meet the outcomes and that the students acquired sufficient knowledge to meet the needs of the clients that they would serve (refer to Table 6). The researcher considers this claim to be appropriate as the outcomes outlined were clearly in keeping with literature in the field of APD. Additionally, the respondents reiterated that poor accessibility and financial constraints limited access to behavioural and electrophysiological assessments, coupled with a lack of appropriate standardised material, prevented them from meeting the desired outcomes for a curriculum in APD.

\section{Silences [what does the curriculum say nothing about].}

The silences are captured in Table 6. Each curriculum offered at the training institutions, demonstrated that in theory they appeared to cover all areas as per the predetermined categories as outlined in the methodology. The majority of the training institutions appeared to offer a curriculum focussing on generic knowledge and skill required in assessing and managing a child presenting with APD, although, two of the five training institutions indicated that students at their institutions were informed of issues pertaining to the South African context. This was not transparent in the course descriptors.

Although the challenges with regard to training in APD 
were acknowledged, what the respondents were silent about was whether and how the training programmes in APD dealt with the issues outlined in table 6 in training and sufficiently equipped the students in dealing with these challenges. Additionally, were other contextual and socio-political issues addressed? However, at this juncture it has to be acknowledged that the respondents were not directly asked about these issues and their inclusion in their course in the questionnaire. The questionnaire was probably not explicit enough in probing for this information.

The last aspect of curriculum analysis is policy analysis. The researcher was unable to determine the kinds of policy/s adhered to in the training, as they were not explicitly referred to in the course descriptors. The assumption is that as professional speech-language therapists and audiologists function within the ambit of the HPCSA and the training programmes are submitted to regular evaluations of their programmes by the professional board of the HPCSA.

The minimal competency profile document developed by the Professional board for Speech - Language and Hearing profession of the HPCSA (2003), are guidelines that direct the training of speech-language therapists and audiologists in South Africa. In this document the minimal competency requirements for speech-language therapists and audiologists with regard to practice in the field of APD is discussed. It is clearly stated that assessing and remediating the client with APD falls within the competencies of the both the audiologist and speech-language therapist, however, the speech-language therapist is disallowed from conducting the diagnostic audiometric test battery to diagnose a child with APD.

The competency profiles and exit level outcomes document that was recommended to serve as a blueprint for training speech-language therapists and audiologists was ratified in 2003, (HPCSA,2003), after the data for the present study was collected. However, the competencies and outcomes stipulated in this document with regard to the area of APD would need to be adopted by all training institutions, ensuring that their curricula are in keeping with current policy that governs the profession.

To conclude, the curricula provided by the training institutions under study were evaluated using the curriculum analysis schema (Jansen \& Reddy, 1998). Application of the curriculum analysis schema enabled the researcher to obtain clear insight into the curricula offered in APD at the training institutions under study. On the whole the curricula are sufficient in scope to address the needs of clients who present with an APD and the researcher acknowledged the problems and challenges facing educators in the field of APD which impact on the training. However, the researcher called for transparency with regard to key issues that permeate the context that South African graduates in speech-language therapy and audiology work in. Current policy in place by the HPCSA is viewed as a positive step in creating some standard in the area of training in APD. However, greater consistency is required in training among the training institutions in South Africa with regard to APD.

\section{CONCLUSION}

The results revealed that despite the differences that existed in the training programmes offered, all five training institutions studied indicated that both speech-language therapy and audiology students receive theoretical training in APD. Four of the five institutions indicated that students received clinical training in the area of APD. All five training institutions under study offered a commitment to training in APD by providing lectures and clinics in the area.

Additionally, by offering joint training in APD to audiology and speech-language therapy students it engenders the promotion of multidisciplinary team work when assessing and remediating APD. This is fundamental to determine the functional impact of the diagnosis and to guide treatment and management of the disorder and associated deficits (ASHA, 2005). The conclusion drawn is that the training institutions in South Africa were meeting the international imperative when it comes to training in the field of APD.

It was further ascertained that the curricula offered locally were comparable to that offered internationally. This opinion is sanctioned by Uys and Hugo (1997, p.25) in the following quotation, "Professional programmes at the higher education levels should prepare the professional of the future (the student of today) to meet the needs of South Africa, while still maintaining the scientific and professional standards of the international market".

Apart from being internationally competitive the curricula offered locally had to be relevant to the South African context. Curricula need to be revised at appropriate intervals to ensure that they reflect the current trends in health care and satisfy the changing needs and requirements of the health care professionals (Druck \& Ross, 2002). It was observed that all training institutions did not explicitly indicate whether the students are trained to understand, assess and remediate APD within the South African context. Additionally, outcomes that allowed for the critical appraisal of the essential knowledge areas with regards to the South African context were not highlighted. Although this was not transparent in the curricula on APD, the researcher acknowledges that as early as 1996, representatives from the various training institutions began discussions on changing the educational programmes offered. This process can be accelerated within the present and favourable transforming post - apartheid atmosphere. The ideal of offering relevant, effective and accountable vocational training programmes as suggested by Hugo (1998) can become a reality.

Speech-language therapists and audiologists working within the South African context are required to possess the necessary knowledge and skills to work in the area of APD, and to be aware of issues that may impact on the assessment and remediation of APD in children in South Africa. These are issues pertaining to cultural and linguistic diversity of the South African population, poverty, HIVAIDS, and the discrepancy in access to education. The content of the APD curricula should be related at all times to these factors to adequately prepare professionals for the local context and to the benefit of those whom we serve. If these issues are not addressed in the programmes offered at the training institutions currently, the researcher recommends their inclusion. Speech-language therapists and audiologists are required to provide an equitable service to all clients including black African first language speakers, specifically within the field of APD. They need to possess the necessary knowledge, skill and attitudes in assessing and remediating these clients who may not benefit from practices that suit a monolingual, monocultural clientele

Professional educators have a responsibility to themselves, their students and their programmes to ensure that the practices that they advocate are motivated by the best of current science. Additionally, for the South African context the curricula have to be coupled with a critical appraisal of APD in light of issues pertaining to the South African context. The profession of Speech-language Therapy and Audiology have to provide an equitable service to all clients irrespective of race or language, in keeping with the political imperative. This is imperative if one is seeking to transform curricula and for the purposes of this research specifically in the area of APD. 


\section{REFERENCES}

American Speech-Language-Hearing Association. (ASHA) (1996). Central Auditory Processing: Current status of research and implications for clinical practice. Task force on Central Auditory Processing consensus development. American Journal of Audiology, 50 (2), 41-52.

American Speech-Language-Hearing Association. (ASHA). (2005). (Central) Auditory Processing Disorders: Technical report. Retrieved April 22, 2005, from http://www.asha.org/members/desref-journals/seskref/default.

Bailey, D.M. (1997). Research for the health professional. A practical guide (2nd ed.). Philadelphia: F.A. Davis Company.

Bellis, T.J. (1999). Editorial: Central auditory processing disorders in children. Journal of the American Academy of Audiology, 10, (6).

Bellis, T.J. (2002). Central Auditory Processing Disorders (Dcom 730).

Bellis, T.J. (2003). Assessment and management of Central Auditory Processing Disorders in the educational setting. From science to practice (2nd ed.) New York: Delmar Learning/Singular.

Bellis, T.J. (2004). Redefining auditory processing disorder: an audiologist's perspective. The Asha Leader, 6, 22-23.

Boughey, C. (2005). A brief guide to outcomes based education and the national qualifications framework. Rhodes University: Academic development centre. Retrieved on June 25, 2005 from http://www.ru.ac.za/ academic/adc/obeguide.html

Campbell, N.G., \& Wilson, W.J. (October, 2001). RSA CAPD Taskforce: An Update. Proceedings of the SASLHA KZN Conference. Wild Coast Sun, South Africa

Chermak, G.D. (2003). It takes a team to differentially diagnose APD. The Hearing journal, 56(4), 71.

Chermak, G.D., Traynham, W.A., Seikel, J.A., \& Musiek, F.E. (1998). Professional education and assessment practices in central auditory processing. Journal of the American Academy of Audiology. 9 (6), 452-465.

Clark, D. (2000). Introduction to Instructional System Design. Created July 13, 1995. Updated November 6, 2000. Retrieved on May 16, 2005, from http://www.nwlink.com/ donclark/hrd/sat $1 . h t m l$

Druck, E., \& Ross, E. (2002). Training, current practices and resources of a group of South African hospital - based speech-language therapists and audiologists working with patients living with HIV/AIDS. The South African Journal of Communication Disorders, 49, 2-16.

Drummond, A. (1996). Research methods for therapists. London: Chapman \&Hall.

Fourie, L. (1998). The role of the communication pathologist in managing the school child with auditory processing disorders. Unpublished master's dissertation. University Of Pretoria, South Africa.

$$
\text { ! }
$$

Gerwel, J. (1991). Intellectuals in a changing South Africa. David Webster Memorial Speech, University of the Witwatersrand, Johannesburg.

Hugo, R. (1998). Communication pathology: The way in Africa. The South African Journal of Communication Disorders, 45, 3-9.

Hall, J.W. (1999). CAP In Y2K: An introduction to audiologic assessment and management. The Hearing Journal, 52 (10), 35-42.

Health Professions Council of South Africa (HPCSA). (2003). Report of the ad hoc committee on the competency profile of speech-language therapists and audiologists. Professional Board for Speech-Language and Hearing Professions. South Africa.

Henri, B.P. (1994). Graduate student preparation tomorrow's challenge. $A S H A$, $36,43-46$.

Jansen, J.D. (1998). Curriculum reform in South Africa: A critical analysis of outcomes-based education. Cambridge Journal of Education, 28,321-331.

Jansen, J.D., \& Reddy, V. (1998). Curriculum analysis. A reference manual. Unpublished document. South Africa: Centre for Educational Research and Policy, University Of Durban-Westville.
Jerger, J., \& Musiek, F. A. (2000). Report of the Consensus Conference on the Diagnosis of Auditory Processing Disorders in School Aged Children. Journal of the American Academy of Audiology, 11,467-474.

Jerger, J., \& Musiek, F. A. (2002). On the diagnosis of auditory processing disorder. A reply to "Clinical and research concerns regarding the 2000 APD consensus report and recommendations". Audiology Today, 14(2), 19 -21 .

Kathard, H. (1999). Transformation of educational and professional practice in speech- language pathology. Proceedings of the 1999 Speech Pathology Australia National Conference. Australia, 260-269.

Katz, J.A. (1994). Handbook of clinical audiology (3rd ed.). Baltimore: Williams and Wilkins.

Katz, J.A. (2002). Clinical and research concerns regarding the 2000 APD consensus report and recommendations. Audiology Today, 14(2), 14-18.

Keith, R.W. (2002). Is evaluating Auditory processing disorders in your scope of practice. The Hearing Journal, 55(5), 10.

Leedy, P.D. (1997). Practical research planning and design. New Jersey: Prentice Hall, lnc.

Mc Millan, J.H., \& Schumacher, S. (2001). Research in education. A conceptual introduction (5th ed.). New York: Addison Wesley Longman, Inc.

Mokgalabone, M.B. (1998). Reconceptualising teaching models in teacher education. Perspectives in Education, 17(2), 13-37.

NCGIA GISCC (2005). Learning Outcomes. Retrieved June 6, 2005, from http://www.ncgia.ucsb.edu/education/curricula/giscc/units/format/ outcomes.html.

Neuman, W.L (1997). Social research methods. Qualitative and quantitative approaches (3rd ed.). Boston: Allyn and Bacon.

Norris, B. (2000). Managing Cultural Diversity within Higher Education: A South African Perspective. Intercultural Communication, ISSN 1404 1634, April, Issue3.

Peck, D.H., Gressard, R.P., \& Hellerman, S.P. (1991). Central auditory processing in the school aged child: Is it clinically relevant? Journal of Developmental and Behavioral Pediatrics, 12 (5), 324-326.

Pillay, M. (1997). Speech-language therapy and audiology: Practice with a black african first language clientele. Unpublished Master's Dissertation, University Of Durban-Westville, Durban.

Pillay, M., Kathard, H., \& Samuel, M.A. (1997). The curriculum of practice: A conceptual framework for speech language therapy and audiology practice with a Black African first language clientele. The South African Journal of Communications Disorders. 44,109-117.

Richard, G. (2004, March 30). Redefining auditory processing disorder: A speech-language pathologist's perspective. The Asha Leader, 7, 21.

Schminky, M., \& Baran, J.A. (1999). Central auditory processing disorders. An overview of assessment and management practices. Deaf - Blind Perspecives, $7(1), 1-7$.

Schubert, W.H. (1986). Curriculum. perspective, paradigm and possibility. New York: Macmillan Publishing Company.

Strydom, A.H., \& Fourie, M. (1999). Higher education research in South Africa: Achievements, conditions and challenges. Higher Education, 38(2), $155-167$.

Sykes, S., Tucker, D. \& Herr, D. (1997). Aural rehabilitation and graduate audiology programs. Journal of the American Academy of Audiology, 8(5), 314-321

Uys, C.1., \& Hugo, R. (1997). Speech - language pathology and audiology: Transformation in teaching, research and service delivery. Health $S A, 2$ (2), 23-29.

Wertz D., Hall J.W., \& Davis, W. (2002). Auditory processing disorder: Management approaches past to present. Seminars in Hearing, 23, 277-284.

Wilson, W.J., \& Campbell, N.G. (2000). RSA CAPD Taskforce: Business Plan. 


\section{APPENDIX A}

Layout of the questionnaire

\begin{tabular}{|l|l|l|}
\hline \multicolumn{1}{|c|}{ SECTION } & \multicolumn{1}{|c|}{ AMM } & \multicolumn{1}{c|}{ QUESTIONS } \\
\hline Section 1 & Biographical and background information & Questions 1-6 \\
\hline $\begin{array}{l}\text { Section 2 \& } \\
\text { Section 3 }\end{array}$ & $\begin{array}{l}\text { Sub aim 1- Investigating the nature of the current undergraduate APD curriculum } \\
\text { (theoretical and clinical) offered at all tertiary institutions training communication pa- } \\
\text { thologists in South Africa. }\end{array}$ & Questions 7-21 \\
\hline
\end{tabular}

\section{APPENDIX B}

Description of and justification for the questions included in the questionnaire.

\begin{tabular}{|l|}
\hline \multicolumn{1}{|c|}{ SECTION 1 } \\
\hline QUESTIONS \\
\hline Question 1 \\
- Qualifications \\
- Training institution \\
- Year in which qualifications were \\
obtained and completed \\
- Wurk experience \\
- Number of years practising \\
- Type of experience accrued \\
- Number of years teaching, and in \\
particular in the area of APD \\
teachirig, i.e. as a clinical tutor or \\
lecturer? \\
\hline
\end{tabular}

Question 6

Information on the programme offered at the institutions

The higher education system in South Africa has undergone rapid transformation. This is due to the major challenges that it is faced with. This includes the redress of past inequalities, the transformation of the system or a new social order, meeting pressing national needs, and responding to new realities and opportunities (Strydom \& Fourie, 1999, p.162). The restructuring of education had implications on the training of SLTA's too. In particular there has been rapid transformation in the past five years. Most of the training institutions adopted the modular degree structure and the entire programmes at some institutions have changed. Some of the institutions ceased offering the dual qualification and commenced with a programme that trained both Speech-language

therapists and Audiologists but with a specialist qualification as either a Speech-language therapist or Audiologist. Hence, the need for this question. The researcher has to position the information on the curriculum received in light of the programme offered. Are both Speechlanguage therapists and Audiologists trained in the area? This information is valuable as both Speech-language therapists and,Audiologists play pivotal roles in the management of clients with APD.

\section{SECTION 2}

\section{DESCRIPTION OF THE APD PROGRAMME}

Questions 7-9

To refer back to the definition of the term curriculum this section targets what is taught (the syllabi) and how it is tauaht (the teaching and leaming process)

- Description of the theoretical programme in APD

This section will provide the researcher with invaluable information on the current curricula offered in APD. Questions posed provided the researcher with information as to what year of student received lectures in the area of APD with a breakdown of the teaching time. In addition subjects were required to comment on the effectiveness of the structure employed by their training institutions. Questions 7-9 targeted the academic programme.

\section{Questions 10-16}

- Description of the clinica programme in APD.

Similarly, questions were asked to obtain information on the structure of the clinical programme in APD, with questions probing when clinical training in the area of APD commenced for learners, the manner in which the clinical programme to APD is structured and how clinical exposure is obtained.

Questions 10-16 targeted the clinical programme

\section{SECTION 3}

\section{GENERAL}

Questions 17-21

Here the researcher acknowledged the challenges faced by educators training Speech-language therapists and Audiologists in South Africa. The researcher provided the respondent with an opportunity to reflect on challenges and recommend changes. In addition it was imperative to determine whether respondents teaching in the area are aware of and are keeping abreast of recent developments in the area of APD in South Africa. 


\section{APPENDIX C}

\section{CENTRAL AUDITORY PROCESSING DISORDERS (DCOM 730)}

(Bellis, 2002)

TIME ALLOCATION: 41 LECTURE PERIODS x 50 MINUTES = 34 HOURS.

\section{COURSE DESCRIPTION}

The course will acquaint students with current perspectives regarding the science underlying central auditory processing, the relationship between CAPD and various learning/language disorders, methods of screening for and diagnosing CAPD in children and adults, and methods of developing deficit-specific management programs for CAPD. Also included will be topics related to programming and service delivery. The need for an interdisciplinary team approach to CAPD assessment and management will be emphasised. Because of the complexity of the topic of central auditory processing and its disorders, students should not expect to become clinically competent in this area merely by taking DCOM 730. However, at the end of this course, students should be familiar with the fundamental principles of central auditory processing disorders so that they can begin the process of developing clinical competence in this area through additional study and clinical experience.

\section{LEARNING OBJECTIVES}

After taking this course, students will:

Discuss presumed neurological bases for central auditory processes

Identify relationships between CAPD and language, learning and communication

Discuss methods of screening for CAPD

Delineate purposes of central auditory assessment

Identify subcategories of central auditory tests

Discuss interpretation of central test findings

Discuss the rationale behind deficit-specific management for auditory processing disorder

Identify several management strategies appropriate for individuals with a auditory processing disorders

AN OUTLINE SYLLABUS, REQUIRED TEXTS AND READINGS,

AND ASSESSMENT STRATEGIES WERE PROVIDED. 